\title{
Dissonant Heritage as a By-Product of the Postwar Agrarian Reform in Poland From Postmemory to Ethnoarchaeology
}

\section{Autoethnography and Postmemory}

Initially, the notion of 'postmemory' was unclear to me, however, it drew my attention and seemed promising. I learnt about the perspective of Marianne Hirsch and the essence of postmemory (Hirsch 1997) while studying Anthropology at the University of Łódź, during a lecture of Professor Katarzyna Kaniowska dedicated to the memory as a cultural phenomenon. I immediately enriched my humanist dictionary with a new, attractive entry, which - as it seemed to me at the time - did not exist outside the academic context. Postmemory as a research category was added to my ethnographic toolbox. It opened to me, as a cultural anthropologist, a perspective that, without this category, had no raison d'etre. Thanks to 'postmemory' what was far (in temporal terms) and methodologically impossible suddenly became close and possible.

What is the children's image of their parents' experiences? Postmemory as a research category validated - as a subject of humanist reflection - the memory of those who did not experience a given historical context but grew up surrounded by its echoes, in an atmosphere of recollections passed down in the family from generation to generation. Postmemory differs from memory because of the generational distance, and from history because of the deeply personal attitude (Hirsch I997: 22). Synthesising the complex essence of postmemory, Kaniowska concludes that (I) by studying it, one can understand the personal attitudes and beliefs of contemporary people with regard to the facts forming a significant part of their family history; (2) postmemory, as it refers 
to the experiences of one's loved ones, generates the sense of obligation to empathise and to make up for losses, which does not allow the person burdened with postmemory to break free from the solidarity with their loved ones who experienced 'it', or from the duty to take a stance on the past; (3) and finally, postmemory is a material individuals use to construct their identity and autobiographical self-awareness (Kaniowska 2014).

In my case, postmemory soon transformed from a really promising research category of enormous heuristic value into a part of my life. I clearly realised the power of postmemory not within the academic discourse but within the social practice, and I experienced this firsthand. Ultimately, I accepted the fact that postmemory really works, that, like it or not, I am its 'medium', and that I preoccupy myself with subjects which go beyond my experience and form a part of my family history. The mood of the article is emotional, confessional, and autoethnographic, which is distinctly different from the matter-of-fact academic style, because I write about my own postmemory and what it obliges me to do mostly as a member of the family the biography of which includes difficult heritage, but also as an ethnographer and cultural anthropologist.

What bothers me and what I have to work through is the postwar agrarian reform, the beneficiaries of which were, among others, my great-grandparents - Józef and Józefa Skorupa - farmers from Kolonia Ujazd (Ujazd Commune, Tomaszów Mazowiecki District, Łódź Province). They benefited from the division of the so-called post-German land. What was a stroke of luck for them, for their neighbours - German settlers - was a catastrophe, breaking their biographies in half. Many of them had been born here. They had no other homeland. Their world started and ended here. They took care of their farmsteads and sowed their fields until the implementation of the agrarian reform and repatriation. There was much land to divide after they had left, and there were many landless and small Polish farmers like my great-grandparents. In the I930s, in Kolonia Ujazd, out of a total of fifteen households, four were occupied by German settlers, Protestants, whereas in nearby Maksymów, there was not a single Catholic. Based on private meetings with my grandmother's neighbours, I know that many of the families living today in former German households have no idea that difficult history is boiling up here, right underneath the hustle and bustle of everyday life. The postwar reform confiscated not only their houses and land, but also their identity. I am convinced by the arguments of Krzysztof Woźniak, who says that in this context, the word 'settler' is better than 'coloniser' because the latter connotes the judgement of the value of cultures, and refers to the myth of a German - Kulturträger, who justifies migration with the civilisation mission in the East. What is more, the epithet 
I cannot avoid, following the rhetoric of my grandmother - 'German' - is also out of place; it is a popular mental shortcut diminishing the complex social and cultural identity of Western settlers. According to Woźniak, they migrated from different countries, sharing the language - mostly German - and religion (Protestantism) (Woźniak 20I3: 7-II).

I was introduced to this difficult historical context by a post-remembering person - my grandmother, who was born in 1937 in Kolonia Ujazd, which means that when the agrarian reform was implemented she was only a child. Is it normal for children to pay attention to the personal details of their neighbours? Even though German settlers 'disappeared' from Kolonia Ujazd more than 70 years ago, my grandmother can still distinctly recall their names and say who now tills the land of the Puchsteins, the Schefflers, the Steinbarts, the Baumgarts, the Plantzes etc. She translates foreign names into Polish, simplifies and adapts them, as if they were as Slavic and local as Skorupa, Kopeć, Pryczek, Bożyk, or Sankowski. To her, Mr. Schätzke from Maksymów, a neighbour she last saw as a child, is Mr. Sieczka (which means 'chuff' in English); after the war, thanks to the reform, his land was handed over to my great-grandparents, adding to their modest pre-war acreage a strip of land between the main road (today it is a tarmac road) and the meadows at the river. My grandmother remembers Gustav Puchstein, who was forced by the socialist authorities to briefly work on my great-grandparents' farm after the war, as Gosiek. The agrarian reform left us with not only difficult heritage, but also piles of documents. I found Gosiek and his siblings in an archive in Tomaszów Mazowiecki. Dusty cardboard folders with seemingly innocent titles: "Rolnictwo i reforma rolna" ("Agriculture and Agrarian Reform”) (1945), "Ewidencja Niemców z terenu gminy Łazisko" ("A Register of Germans from the Łazisko Commune") (1946-1947), and "Ewidencja Niemców" ("A Register of Germans") (1948) deprecate the tragic circumstances of the reform implemented a few years earlier and of the repatriation of Western settlers, men and women, young and old, those born 'there' and those born 'here'. The folders contain the peasants' letters of application for the post-German land, forming a record of harm, fears, dreams, and authentic and false images; long lists with full names of Germans - repatriates, who would soon disappear from the local cultural landscapes; lists of addresses: Strassfurt, Karsdorf, Mittweida, Bestensee, Schmorkau and other small towns in East Germany (APTM, 2I, 390), where the repatriates would go; protocols on the distribution of former German homesteads among Polish neighbours; lists of Germans who would partly compensate for the wartime damage by working on the farms of their Catholic neighbours. 
Here's Gosiek! Gustav was a son of Eduard and Emma Puchstein, my great-grandparents' neighbours. He was born in the same village as my grandmother on July 28, 1934, which means he was three years older than her. What would have been their relationship had there been no war, reform, and repatriation? As an eleven-year-old, he was sent to work on the farm of the Skorupas. His older brother, Ewald, was sent to the Bożyks. The documents do not mention their sister, Elisabeth (little Betti?). What happened to their parents, Eduard and Emma? What did they miss? What were they concerned about? My grandmother was too small to remember this, but I am ready to postremember and to turn this experience into a scientific activity.

\section{The Postwar Agrarian Reform in Poland - the Origins of the Dissonant Heritage}

The notion of the 'postwar agrarian reform in Poland' is another mental shortcut based on two historical inaccuracies. First of all, even though the reform was a process stretched over a period of several years, the Decree of the Polish Committee of National Liberation of September 6, 1944, on the implementation of the agrarian reform (hereinafter referred to as the Decree) came into effect at the end of the war, during the Warsaw Uprising. Second of all, as Łukasz Skarżyński emphasises, even a hypothetical form of future Poland was unknown at the time (the Eastern front reached the Vistula River), and yet socialist authorities, anticipating the facts, initiated division of the land (Skarżyński 20ı6: 133).

Polish historical and sociological exegeses of the agrarian reform and its images in the literature mostly focus on political, economic, sociological, cultural and psychological circumstances of dividing among Polish peasants the land previously owned by the landed gentry - a social group robbed by the socialist authorities of what constituted a part of its ethos and the basis of its existence. For example, Anna Wylegała studied the peasant experience of the agrarian reform, but only in the context of the relationships between the peasantry and the dispossessed landed gentry. Without yielding to the temptation to present the problem from the macrohistorical perspective, which dominates in the scientific discourse, and shifting the emphasis from political and economic aspects to the socio-cultural dimension of the reform, Wylegała appreciated the emotions and attitudes of the social actors directly affected by the agrarian reform, namely the peasantry and the landed gentry (Wylegała 2017), however, she did not consider the perspective of the German population who - together with the landed 
gentry - was dispossessed based on the same Decree in violation of the right of ownership.

In particular, their fate was determined by Art. 2 b) of the Decree, which sanctioned division of the land owned by the citizens of the German Reich and Polish citizens of German nationality (Decree...). On September 6, 1944, or, as the example of Ujazd shows, even a year or two later, this still was not fully 'post-German land'; the settlers did not disappear from the local landscape right away. For example, the Village Head of Bielina, declared: there are no Germans or other nationalities in the village, there are only Poles here (APTM, 2I, 320) only on December 6, 1947. Andrzej Zieniewicz called the dispossessed, expelled Germans the 'silent Other' in the image of the Polish agrarian reform (Zieniewicz 2017), but he only focuses on the situation of the German population displaced from the Recovered Territories, after the Polish-German border was moved to the Oder-Neisse line. German settlers from villages near Ujazd, who lived in Poland not only after but also before the war, were in a different situation. They, among others, seem to be the true 'silent Other' in the Polish public discourse, however, this is beginning to change on the local level. I write about the activation of memory of the local Germans - settlers, neighbours and landscape designers - in the further part of the paper.

In the context of the agrarian reform, Skarżyński writes that communists acted faced with obsessive hatred of the Polish population towards Germans as the invaders and the willingness to quickly stabilise life after the war (Skarżyński 2016: 134). The proofs include the peasants' letters of application for the post-German land. Even though these are personal sources based on authentic experiences, frequently containing valuable elements of the peasants' autobiographies, they are still burdened with persuasion and ideology: their aim was to convince the socialist authorities to divide the land the way the peasants expected. Thus, one cannot exclude rhetorical practices meeting the demands of the socialist propaganda, a part of which was the discrediting of German invaders and collaborators, to whom, stereotypically, German settlers were included en masse, regardless of their actual emotions and attitudes.

Lavishly pompous, the Polish peasants' letters of application for the land of their German neighbours from the area of Ujazd, long lists of data concerning German inhabitants whom the authorities decided to repatriate, protocols on the division of the post-German land, and documentation of the allocation of German workers to farms that benefited from the reform make us realise how difficult the heritage we deal with is.

Why is the legacy of the local Germans difficult/dissonant heritage? It is impossible to give a factual answer to this question without resorting to the 
invaluable observations of researchers into heritage, developing the theory about the phenomenon. Dissonant heritage is the heritage 'that hurts' or that recall past events not easy to be reconciled with visitors' values and everyday experience (https://dissonantheritage.wordpress.com). This short yet precise definition was created by researchers in the field of the heritage of Italian fascism and Yugoslavian socialism. These research contexts are very important and characteristic in this case. The notions of 'dissonant heritage' and 'difficult heritage' most frequently concern research problems the source of which was the tragic history of the $2 \mathrm{O}^{\text {th }}$ century, and mostly the Second World War, Nazism, totalitarianism, authoritarianism, and their repercussions (e.g. Macdonald 2009; Burström, Gelderblom 20II; Dragićević-Šešić, Rogač-Mojatović 20I4; Battilani, Bernini, Mariotti 2018). The subject of my reflection is not very far from these contexts, and it can even be said that it lies within them. On the one hand the agrarian reform was a tool of postwar totalitarianism (communism/socialism), while on the other hand the dispossession and repatriation of the German population prolonged the tragedy of the Second World War.

In the article of Milena Dragićević-Šešić and Ljiljana Rogač-Mijatović about the tourist attractiveness of the Balkans, the notion 'dissonant heritage' refers to the process of dealing with ambivalent and frequently unwanted past of the region that has a multi-layered and transnational identity. Its different layers have the right to construct past from their own perspectives, which gives space for the discordance and lack of consensus over the heritage (Dragićević-Šešić, Rogač-Mojatović 20I4: II). Even though the region of Ujazd, which is the subject of my reflection, is nowhere near the Balkan multiculturalism, it does not mean that there is no risk of objectivisation of its dissonant heritage. The twofold identity and past of this place - Polish and German, Slavic and Germanic, Catholic and Protestant - may generate forms of memory and oblivion that resemble a constant sum game, with the gain of one player being the loss of a nother: it seems that the fewer those playing for the memory and the past, the easier it is to locate and attack the competing perspective. This cultural rule (or rather a hypothesis that needs to be tested) seems to explain the atmosphere surrounding the idea to protect the place where a Nazi Harvest Festival took place in 1933-1937 (Bückeberg, Germany) as a historic monument. Mats Burström and Bernhard Gelderblom, using this as an example of difficult heritage, write about a confrontation between two perspectives: the one of the local authorities (originators of the idea) and the one of the local population protesting against the protection of the place: It has been argued that local people do not wish to be associated with the Harvest Festival and, with it, 
a shameful Nazi past (Burström, Gelderblom 20Ir: 275). Battilani, Bernini and Mariotti note apropos that the unwanted past becomes an unwanted place. [...] Finally, if dissonant heritage is used to highlight the uniqueness of a place, the distinctiveness can assume a negative connotation (Battilani, Bernini, Mariotti 20I8: I420). Scientific curiosity and research into difficult heritage is one thing, but living surrounded by it is another. This difference is a significant context for those studying heritage. Sharon Macdonald adds that difficult heritage may also be troublesome because it threatens to break through into the present in disruptive ways, opening up social divisions, perhaps by playing into imagined, even nightmarish, futures (Macdonald 2009: I). Thus, on the one hand studying it is an invasive undertaking that generates many ethical dilemmas, but on the other hand the conflict-generating 'infecting' of the public (even if only local) space by pushing difficult heritage out of the shadows fits in with the agonistic concept of democracy of Chantal Mouffe, who contrarily claims that conflict is something positive in a democratic society and that it cannot be avoided. Modern democracy needs it so that the Other can be treated not as an enemy that has to be destroyed but as a respectful opponent that one has to face and whose right to defend one's own ideas is not questioned. Agonists are not antagonists (Mouffe 2013).

Putting aside other aspects and effects of the agrarian reform, I advance the thesis that the difficult post-German heritage in the villages formerly inhabited by German settlers, from which they disappeared after the Second World War, is rooted in the agrarian reform, which changed the demography of these places very quickly by dispossessing and repatriating the German population, and by dividing their land among peasants being the beneficiaries of the reform. The difficulty of this heritage does not lie in the fact that it does not have any heirs; just the opposite - new heirs came before the old ones disappeared, and they are still here. The dramatic essence of this kind of heritage was accurately formulated by Monika Sznajderman: I can live here because none of them are here. They left. They left a void behind them, with memories and things abandoned in $i$, leaving the landscape they had been co-creating for years, writes Sznajderman about her post-Lemko Wołowiec, where she feels like a late guest in someone else's world, a stranger from far away settling in someone else's place (Sznajderman 2019: 33, 34). I could not describe better the affection accompanying me whenever I visit my grandmother in Kolonia Ujazd, cut the grass in the farmyard, help with the harvest, rest in the old apple orchard in front of the house, walk down roads no one will find on the map - roads with no cars, when I watch pear trees run wild and blackberry bushes overgrow former yards, and when 
I destroy the dam built by beavers after the meadows have been flooded by the river in the spring.

The world around me changes right before my eyes. If Jacques Le Goff was right when he wrote that in the European culture agri deserti are the signs of regression, while the clearing and 'withdrawal' of the forest - the signs of civilisation development (Le Goff 1994: 4I), then the issue of using the land near Ujazd, in former German villages, is controversial. The fields that used to be sowed with rye (which does not need fertile soil) by German settlers from Władysławów and other villages sharing its heritage lie fallow or are overgrown with a young forest. Leafing through Rejestr mieszkańców, vol. I, Wsi: Jankówek, Kol. Wtadystawów, Łominy, Józefin from the period I932-I939 (APTM, I6, 824), and I do it slowly so as not to destroy the old, heavy and cumbersome book, I have one question: Is the word 'settlers' appropriate in this context? The word 'colonisers' is based on a stereotype and it is politically incorrect, while the term 'settlers' is too neutral and mechanical, emphasising allochtonism and omitting the whole context of life and landscape co-creation. The word 'inhabitants' seems to fit better as it indicates autochtonism, and it is marked emotionally and symbolically.

The dwindling area of crops and the expansion of the forest go hand in hand with demographic changes. Today, there are only 5 addresses in Władysławów, including the agritourism farm of the Zielińskis - a very important place in the topography of the difficult post-German heritage near Ujazd, which I discuss in the following part of this paper. Before the war, there were more than twice as many. In the archive I 'got to know' the pre-war inhabitants of Władysławów.

The Hentschkes, who took care of Otto Puchstein from Wykno ${ }^{\mathrm{I}}$, lived at number one. Didn't they have their own children? Adam Hentschke, son of Jan and Karolina (née Gust), was from here, he was born in Władysławów on December 22, I888. His wife Emma Hentschke, née Schultz, was born on November 16, I896 in Łączkowice. Protestants.

Marcin and Natalia Grunwald, who were Protestants, lived alone at number two.

August and Marja Nitschke with an adult daughter Ottylja, and with Wanda and Erwin, bastards from their family whom they took care of, lived at number three. Protestants.

I In the paper I write about or only mention numerous villages near Ujazd inhabited by Germans before the Second World War. Villages significant for the topography of the difficult post-German heritage include: Aleksandrów, Ciosny, Dębniak, Józefin, Kolonia Ujazd, Lipianki, Łączkowice, Łominy, Maksymów, Niewiadów, Olszowa-Piaski, Stasiolas, Szymanów, Władysławów, and Wykno. 
At number four: the Guderjans. Protestants. Him - Juljusz, son of Adolf and Wilhelmina, born on October 29, 1877, in Aleksandrów. Her - Natalia, née Lucht, born on August 6, I886, in Szymanów. They had one daughter, Elza-Ottylja, who married Wilhelm Sommerfeld, and four sons: Gustaw, Paweł-Juljusz, Herman, and Emil. Willi Sommerfeld was born in Władysławów on July 9, 1938. He lived with his mother, grandparents, and four uncles. As the Rejestr (APTM, 16, 824) indicates, he was baptised a Catholic. A mistake or a symptom of the assimilation of German inhabitants?

Fryderyka Meier, née Guderjan, lived at number five together with her brother Emanuel Guderjan, who helped her on the farm after her two sons - Gustaw-Aleksander and Artur - had emigrated (to work?) from their home Władysławów to Łódź (I6 Dąbrowska Street) in 1932. Protestants.

Natalia Guderjan, née Gesell, widow of Krzysztof Guderjan (who died in 1935), lived at number six with two daughters - Anna and Olga, and son Artur-Krzysztof; the other son, Erwin, emigrated to Łódź (38 Lipowa Street) a year after his father died. Protestants.

No one lived at number seven at the time.

Stanisława Stange, née Walewska, widow, lived at number eight with her son Wilhelm. The other son, Gottfryd, emigrated to Łódź in 1938. Protestants.

The Beiers lived at number nine. Bruno, son of Karol and Lidja, was born on May 15, 1903, in Widzew (which is now a district of Łódź). Eugenia-Joanna, née Scheibner, was born on November 7 in Łódź. Their children - daughter Herta-Edeltraut (a rare, beautiful Old German name) was born in Łódź in 1933, and son Harry was born in Władysławów in 1936. They emigrated from the city to the country (why?) when Herta was an infant. Protestants.

Julja Lück, née Hiske, widow, lived at number ten in one room. A Protestant. The whole Hiske family occupied the other room: Edward and Emma, their son and five daughters: Pawet, Elly, Irma, Marta, Emma-Joanna, and Wally, all born in Władysławów. Protestants.

The example of Władysławów shows the axiological difference between the notions of 'settlers' and 'inhabitants', measuring the local reference of the word 'minority'. Before the outbreak of the Second World War, many of the villages within a few-kilometre radius of Ujazd were inhabited by Protestants. In Władysławów, all inhabitants were Protestants, with names that definitely sounded foreign. Paradoxically, the failed attempt to make them more familiar through the Polonisation of the spelling only emphasises their foreign origins. In such places as Lipianki and Maksymów, Catholics and Polish peasants with Slavic names and surnames were in the minority (APTM, 16, 829; APTM, 2I, 524). The postwar agrarian reform 'invented' the world anew, allowing this minority 
to settle in someone else's place, and thus giving rise to difficult heritage based on ambivalence that consists of someone else's harm and one's own gain. The reform and its historical background (the war and the socialist propaganda) provided a context within which neighbours - the Other - became strangers in the anthropological sense overnight. This heritage, among other things, stigmatises the beginning of postwar, socialist Poland. As Zieniewicz wrote, it combined liberation with enslavement, hope with falsehood, and affection with hostility (Zieniewicz 2017: 22I). This ambivalence of extreme emotions and attitudes, varying experiences of different social groups, and a multitude of perspectives make the post-German heritage near Ujazd difficult/dissonant.

The cultural landscape was also co-created by Jews - the other 'silent Other'. They lived not only in Ujazd, the local centre of craft and trade, but also in villages that were nearly ecumenical, where Catholics, Protestants and Jews were joined and assimilated through their work on the land and everyday life. However, the existence of difficult heritage of the local Jewish inhabitants is an issue requiring a separate paper.

The modernisation of agriculture, modification of crops, and afforestation of the local landscape are not only environmental but also cultural facts. They prove not only a change in the lifestyle and work style of the inhabitants and their attitudes towards the land as a subject of economic and symbolic evaluation, but also the local way of dealing with dissonant heritage. During pilot ethnographic research conducted in November 2017 on the contemporary post-German heritage in the Ujazd region, which served as an introduction to the planned ethnoarchaeological research, we met Elżbieta and Grzegorz Zieliński, who run an agritourism farm Letnisko-Uroczysko in Władysławów. It is located at the very end of the village in an old, wooden post-German house, which is, unfortunately, one of few preserved buildings of this type in the Ujazd region. Mr. and Mrs. Zieliński, who moved here more than ten years ago from Łódź in search for an alternative to a large city, realised the difficult history of Władysławów thanks to an old man from Germany who was one of their guests. His foreign name contrasted starkly with his quite correct Polish. It turned out that he was born before the war in Władysławów, in a house at the opposite end of the village, which has not been preserved. Today, there is a forest there. The man went to a Polish school in Lipanki, where he learnt Polish. He was surprised that his home village is now located in a forest and that no one sows corn. He remembers the view of Lipanki from Władysławów - the view that is no longer available and only exists in the mental space.

One can become aware of this difference in the local landscape by comparing the contemporary map (even the generally available Google Maps) with a 
pre-war map. Suspiciously regular, as if cut out with scissors of green cardboard, contours of today's forests turn out to be following the arrangement of fields. This is not a primeval forest but evidence of desagrarisation and shrinkage in the area of crops. An unsown field becomes fallow, and after a few decades it is overgrown with a forest.

\section{The Proposed Order of Research Steps}

Researchers who base their projects on private motivations, personal emotions and their own biographical experiences have to be prepared for being accused of lack of 'scientific' neutrality, activation of involvement, and confusing their own lives with science. On the other hand, however, in cultural anthropology, involvement - together with empathy and sympathies - is not a troublesome, embarrassing by-product of research undertakings but an inherent or even valid characteristic of successful research projects (Kaniowska 20IOa; Kaniowska 20Iob). The proposal of ethnoarchaeological research also has this 'outer-scientific' quality, with the source being my own postmemory, a strongly involving impulse obliging me to empathise, act, and make up for losses. This is the first step which determines, or even - considering the imperative nature of postmemory - imposes, the subject and objective of the research undertaking. The aim is to repay the inherited landscape by reviving mentally its past and all those who created it, listing them by name and studying the past boiling up underneath the hustle and bustle of everyday life. It seems that difficult heritage requires some temporal distance in order to become a subject of reflection and research. Perhaps it is the domain of those who post-remember, and not witnesses or those who experienced given historical circumstances themselves.

The second step involves archival research. General registry, registers of residents, vital records, documents concerning the agrarian reform and repatriation are the traces of the lives of German inhabitants and their tragic disappearance from the local cultural landscape. They allow to reconstruct the genealogical trees and migration trails of individuals and whole families, and to identify their stopping points along the migration trails as well as family homes Germans occupied for generations. Thanks to this, one can visit every single house, leafing through old books. And finally, one can realise how difficult the heritage is by reading the letters of application for the land left by the dispossessed neighbours, protocols on the division of the land formerly owned by Germans, and other documents constituting a record of guilt and harm, on which dissonant heritage is founded.

The third step is the actual research based on the synergy of research perspectives drawn from ethnography, cultural anthropology and archaeology. In 
the case of post-German material heritage in villages near Ujazd, ethnoarchaeological research should focus on the documentation of the contemporary, yet rooted in history, state of the following elements:

- Urban layout of the village (topography, appearance of the village may refer to the nature and origins of the settlement);

- Baulks, field borders (form and shape);

- Roads and paths (main and peripheral roads, official and unofficial, public and private, road surface types, condition of the roads, roadside trees, crossroads, road and direction signs);

- Farmsteads (arrangement and form of farmsteads, houses, barns, sheds, cellars and other buildings; their condition, material, architectural ornaments, equipment, and forms of contemporary transformation);

- Home orchards (tree species, orchard layout, age and condition of the trees);

- Home gardens (layout, plant species);

- Small-scale architecture (wells, dovecotes, beehives, outside toilets, benches, fences, and gates);

- Public utility buildings (inns, schools, houses of prayer; their present condition and forms of contemporary transformation);

- Industrial buildings (mills, windmills, oil mills, smithies, sawmills; their present condition and forms of contemporary transformation);

- Hydro-engineering structures (ditches, drains, pools, ponds, water gates on rivers, bridges, embankments);

- Cemeteries (fences, cemetery paths, cemetery layout, graves and their condition, inscriptions, crosses, the extent to which they are overgrown). Each of these elements of the post-German material heritage corresponds with non-material aspects forming a kind of its 'fourth dimension'. For example, contemporary lights that can be found on post-German cemeteries prove how people deal with this heritage (it is an active form of remembrance of German residents). On the other hand, moss-grown, barely legible inscriptions on the graves indicate a completely different process. A similar situation was encountered by Macdonald when studying the place of the NSDAP rallies in Nuremberg, where she met a man in the overgrown with grass stand of the Stadium Zeppelinfeld, who shared with her his reflection on this heritage: grass growing is like forgetting (Macdonald 2009: 8).

Zieniewicz notes that what was divided among the peasants as beneficiaries, who thus had their share in power, was not only land but also all possessions, positions, and jobs (Zieniewicz 2017: 223). This is why ethnoarchaeological research should consider not only material but also non-material aspects of the heritage. This aim can be achieved by conducting ethnographic interviews 
with the local population. However, as Wylegała rightly points out, interviews about the circumstances of the agrarian reform, requiring casting one's mind back to more than 70 years ago, have the obvious disadvantage related to the passage of time: you can only conduct them with people who were children or teenagers at the time (Wylegała 20I7: 280). However, there is a solution to this problem. This is where the category of 'postmemory' comes in handy, inviting to speak those who cannot or barely remember division of the land previously owned by their German neighbours, but were raised here and have their own opinions about the agrarian reform and about what happened to the German settlers just because they live in post-German homesteads, and they approach this heritage in a specific way, practising different forms of remembrance and oblivion, and creating their identity and autobiographic self-awareness the way they do. After all, heritage is a question of selection and acceptance, planning and management (Ashworth 20I5), thus being a dynamic subject of research that requires, with each fluctuation (which, in the case of heritage, is not a rare phenomenon), new documentation, inventory or professional interpretation and critical evaluation.

Ethnographic interviews allow to select for an archaeological inventory survey places of significance from the perspective of post-German heritage which require to be documented first. This idea goes hand in hand with the observation of Battilani, Bernini and Mariotti that there are monuments, practices or memories, which deserve specific attention due to the origin and features of their dissonance (Battilani, Bernini, Mariotti 2018: 1420).

\section{Local Patriotism and Professional Ethnoarchaeology}

Heritage is a subject of studies and reflection of researchers from the academic circles and, more and more frequently, regional experts, local patriots, history enthusiasts, local government members and politicians, who take matters into their own hands as local experts, cultural managers as well as heirs and creators of the cultural landscape. Academic and professional ethnoarchaeology of heritage should open up to local research initiatives so as not to force the door that might have already been opened by local activists conducting their studies outside the professional context, and yet offering enormous heuristic value. Local (internal) researchers have extremely valuable resources in the form of a network of contacts, informal relationships with the local inhabitants, mutual trust, and great topographic erudition. These are the resources external researchers lack; theoretical training, proper qualifications, academic degrees, research practice, and a professional toolbox might not be enough to ensure 
research success, particularly with regard to research into difficult heritage, which requires not only factual knowledge, but also a certain context and familiarity or even intimacy.

The pilot research showed that the issue of post-German heritage near Ujazd is a subject of postmemory, local research initiatives and management. Jarosław Cielebon, instructor in the Communal Community Centre in Ujazd (GOK), promotes the concept of a bike trail following German settlements, developed in cooperation with heads of a few villages inhabited by Germans before the war. The idea emerged during the implementation of a different project, the aim of which was to analyse the cultural needs of the local population. It turned out that heads of former German villages wanted to deal with this difficult heritage.

They are people who settled in these villages after the war. The present residents see the old buildings and they know who built them. Some of them would like to learn their history. Perhaps their fathers were not curious about it. They were afraid and aware of the fact that throwing away owners of these houses, people who had worked this land for generations, wasn't right. [...] During the meetings of the GOK's History Club we selected places to be catalogued, we drew up a list of people we wanted to talk to, and we learnt the interview technique. [...] During further meetings, we got to know the characteristics of post-German architecture and, unfortunately, we realised that our chances of finding an intact farmstead were slim. However, we know that there are some houses, barns or stables. And cemeteries. [...] You have to bear in mind that the GOK's History Club mostly consists of elderly people, but we have many plans. We have to implement them one by one. At the moment, we are collecting documents and looking for witnesses. We may be able to show the remains of German farmsteads, but we are mostly shocked by the recollections of people who remember that world. It's like landing on a different planet, which is surprisingly different and, in consequence, strange. Those who don't know Janka Piwowarska's stories about the school in Lipianki, about good relationships between Poles and Germans before the war, about how the situation changed dramatically during the war, and about the sudden disappearance of the German population after the war should wait impatiently for the next meeting of the GOK's History Club. [...] At the beginning of November, I was unexpectedly visited by a group of academics from the University of Łódź, who are going to run a research project on German settlement in the Łódź Province. I could not believe this. They visited GOK by a pure chance but it seems that both sides are very happy about this 'coincidence' (Cielebon 20I7).

This citation includes many arguments and theses from my paper, presenting a perspective that is local yet close to my research proposal. First of all, Cielebon, even though he does not use the term 'difficult heritage', 
indicates its existence in the context of lack of curiosity about post-German heritage among the witnesses of the agrarian reform and repatriation of the German population. These circumstance were ethically and politically controversial (dispossession, repatriation), so people probably did not want to or were afraid to recall them. Only those who post-remember (present heads of former German villages) have the courage to face history. Second of all, Cielebon emphasises that the social (the age of the potential internal researchers) and substantive (training in the interview technique) resources of history enthusiasts are too small to achieve the research goal. This forms the basis for a synergistic combination of the potential of the local research initiative and local experts with a professional ethnoarchaeological perspective (satisfaction with the meeting with academics from the University of Łódź, who have a similar research idea). And third of all, he emphasises two equally significant aspects of cultural heritage - material and non-material - which form the manifestation of the essence and beauty of ethnoarchaeology (post-German houses and memories of German neighbours that used to live in them).

Battilani, Bernini and Mariotti suggest how to deal with dissonant heritage: mostly by involving the local community in discussions on the heritage, and also by going beyond particularistic, parochial interests (Battilani, Bernini, Mariotti 2018: I418). Ethnoarchaeological research into difficult post-German heritage as a product of the agrarian reform in Poland should consider the above suggestions; the first one - considering not only the issue of awareness and knowledge, but also methodological and research benefits of working with local experts and local inhabitants. The second demand results from, among other things, the general transformation faced by the contemporary discourse on memory, heritage and the past, particularly in the context of the Second World War. Krzysztof Pomian, apart from its other characteristics (such as democratisation, anthropologisation, existence in an interdisciplinary context), writes about the perspective of globalisation which helps many researchers to go beyond specific countries and national interests. This is also about a sensitive approach, the basis for which is the discrediting of xenophobia responsible for all great catastrophes of the $20^{\text {th }}$ century, which is not focused on successes of one's own group at the cost of a different group, but on the universal human community of suffering (Pomian 20I4: 24-25). This is important, particularly with regard to the study of difficult heritage, which is a meeting place for two ethnic and national groups whose relationships are the subject of the antagonising stereotype and myth. 


\section{Bibliography}

Ashworth G. (2015), Planowanie dziedzictwa, Międzynarodowe Centrum Kultury, Kraków. Battilani P., Bernini C., Mariotti A. (2018), How to Cope with Dissonant Heritage: a Way towards Sustainable Tourism Development, "Journal of Sustainable Tourism”, 26 (8), p. 1417-1436, https://doi.org/10.1080/09669582.2018.1458856

Burström M., Gelderblom B. (2011), Dealing with Difficult Heritage: The Case of Bückberg, Site of the Third Reich Harvest Festival, "Journal of Social Archaeology", 11 (3), p. 266-282, https://doi.org/10.1177/1469605311417054

Dragićević-Šešić M., Rogač-Mijatović L. (2014), Balkan Dissonant Heritage Narratives (and Their Attractiveness) for Tourism, "American Journal of Tourism Management", 3 (1b), p. 10-19.

Hirsch M. (1997), Family Frames. Photography, Narrative and Postmemory, Harvard University Press, London.

Kaniowska K. (2010a), Skąd się biora etyczne problemy badań antropologicznych?, [in:] K. Kaniowska, N. Modnicka (ed.), Etyczne problemy badań antropologicznych, Polskie Towarzystwo Ludoznawcze; Instytut Etnologii i Antropologii Kulturowej Uniwersytetu Łódzkiego, Wrocław-Łódź (Łódzkie Studia Etnograficzne, 49), p. 7-16.

Kaniowska K. (2010b), Etyczne problemy badań antropologicznych, [in:] K. Kaniowska, N. Modnicka (ed.), Etyczne problemy badań antropologicznych, Polskie Towarzystwo Ludoznawcze; Instytut Etnologii i Antropologii Kulturowej Uniwersytetu Łódzkiego, Wrocław-Łódź (Łódzkie Studia Etnograficzne, 49), p. 19-31.

Kaniowska K. (2014), Postpamięć, [in:] M. Saryusz-Wolska, R. Traba (ed.), Modi memorandi. Leksykon kultury pamięci, Wydawnictwo Naukowe Scholar, Warszawa, p. 389-392.

Le Goff J. (1994), Kultura średniowiecznej Europy, trans. H. Szumańska-Grossowa, „Volumen”; „Klon”, Warszawa.

Macdonald S. (2009), Difficult Heritage. Negotiating the Nazi Past in Nuremberg and Beyond, Routledge, London-New York, https://doi.org/10.4324/9780203888667

Mouffe Ch. (2013), Agonistics. Thinking the World Politically, Verso, London-New York. Pomian K. (2014), Historia - dziś, [in:] E. Domańska, R. Stobiecki, T. Wiślicz (ed.), Historia - dzis. Teoretyczne problemy wiedzy o przesztości, Towarzystwo Autorów i Wydawców Prac Naukowych Universitas, Kraków, p. 19-36.

Skarżyński Ł. (2016), Dekret PKWN o reformie rolnej 1944 r. na przyktadzie pótnocnego Mazowsza - ziemia puttuska, "Miscellanea Historico-Iuridica", 15 (1), p. 129-154, https://doi.org/10.15290/mhi.2016.15.01.08

Sznajderman M. (2019), Pusty las, Wydawnictwo Czarne, Wołowiec. 
Woźniak K. (2013), Niemieckie osadnictwo wiejskie między Prosna a Pilica i Wista od lat 70. XVIII wieku do 1866 roku. Proces i jego interpretacje, Wydawnictwo Uniwersytetu Łódzkiego, Łódź, https://doi.org/10.18778/7525-960-5

Wylegała A. (2017), O perspektywie badania chtopskiego doświadczenia reformy rolnej. $Z$ warsztatu badawczego, "Rocznik Antropologii Historii", 7 (10), p. 273-305.

Zieniewicz A. (2017), Czutość i wrogossć przemian (migracje, reforma rolna i socjalizm w perspektywie "prześnionej rewolucji”), “Teksty Drugie”, 6, p. 221-237.

\section{Archival Sources}

State Archive in Piotrków Trybunalski - Tomaszów Mazowiecki Branch (APTM),

"Akta Gminy Ciosny", collection no. 16:

Rejestr mieszkańców, vol. I, Wsi: Jankówek, Kol. Wtadystawów, Łominy, Józefin,

1932-1939, file no. 824.

Rejestr mieszkańców, vol. VII, Wsi: Niewiadów, Szymanów, Lipianki, 1932-1939, file no. 829. State Archive in Piotrków Trybunalski - Tomaszów Mazowiecki Branch (APTM),

"Akta Gminy Łazisko z siedzibą w Ujeździe", collection no. 21:

Rolnictwo i reforma rolna, 1945, file no. 287.

Urząd Reformy Rolnej. Podania na gosp. niem. odmówione. Ujazd, Maksymów, Stasiolas, Cekanów, Matecz, Olszowa-Piaski, Wólka Krzykowska, 1945, file no. 288.

Ewidencja Niemców z terenu gminy Eazisko, 1946-1947, file no. 320.

Ewidencja Niemców, 1948, file no. 361.

Niemcy (ewidencja ludności niemieckiej), 1949-1951, file no. 390.

Księga ludności statej wsi: Bielina, Kol. Dębniak, Wygoda, Wólka, Folwark Teklów, Olszowa-Piaski, Maksymów, tom V, 1895-1931, file no. 524.

\section{Legal Acts}

Decree of the Polish Committee of National Liberation of September 6, 1944, on the implementation of the agrarian reform, Journal of Laws of 1944, No. 4, item 17.

\section{Online Sources}

Cielebon J. (2017), Wywiad z historykiem, instruktorem Gminnego Ośrodka Kultury $w$ Ujeździe, Jarostawem Cielebonem: http://www.cmentarzeewangelickie-lodzkie.pl/ rp_wywiad_jcielebon.php?mn=wywiady (access 10 VIII 2019).

https://dissonantheritage.wordpress.com/ (access 10 VIII 2019). 


\section{Summary}

\section{Dissonant Heritage as a By-Product of the Postwar Agrarian Reform in Poland. From Postmemory to Ethnoarchaeology}

The subject of the paper is dissonant heritage exemplified by former German villages in Central Poland. The agrarian reform (1944) transformed the local social and cultural landscape by removing its German inhabitants. Today, former German farmsteads are occupied by families of the reform beneficiaries - Polish peasants. The paper is personal as it is based on the postmemory of the author, who used archival sources (including vital records and peasants' letters of application for the post-German land) and information from his grandmother, who remembers her German neighbours, in an attempt to 'revive' the multi-cultural past and those who used to be a part of this landscape. The author outlines the concept of ethnoarchaeological research into the dissonant heritage being a by-product of the agrarian reform (1944) in Poland.

Keywords: postmemory, dissonant heritage, cultural anthropology, ethnoarchaeology, autoethnography, agrarian reform after the Second World War in Poland, German settlers, Polish peasants

\section{Streszczenie}

\section{Dysharmonijne dziedzictwo jako produkt uboczny powojennej reformy rolnej w Polsce. Od postpamięci do etnoarcheologii}

Przedmiotem artykułu jest dysharmonijne dziedzictwo przedstawione na przykładzie poniemieckich wsi w Polsce centralnej. Reforma rolna (1944) zmieniła lokalny krajobraz społeczny i kulturowy, usuwając z niego niemieckich mieszkańców. W poniemieckich gospodarstwach, domach żyją współcześnie rodziny beneficjentów reformy - polskich chłopów. Artykuł ma charakter osobisty, opiera się na postpamięci autora, który bazując na archiwaliach (m.in. aktach stanu cywilnego, podaniach chłopów o poniemiecką ziemię) i informacjach od swojej babki pamiętającej swoich niemieckich sąsiadów, próbuje „wskrzesić” wielokulturową przeszłość i tych, którzy byli częścią tego krajobrazu. Autor w zarysie przedstawia koncepcję badań etnoarcheologicznych tego dysharmonijnego dziedzictwa będącego produktem ubocznym reformy rolnej (1944) w Polsce.

Słowa kluczowe: postpamięć, dysharmonijne dziedzictwo, antropologia kultury, etnoarcheologia, autoetnografia, powojenna reforma rolna w Polsce, niemieccy osadnicy, polscy chłopi 
Dissonant Heritage as a By-Product of the Postwar Agrarian Reform in Poland...

\section{Photographs and Documents}

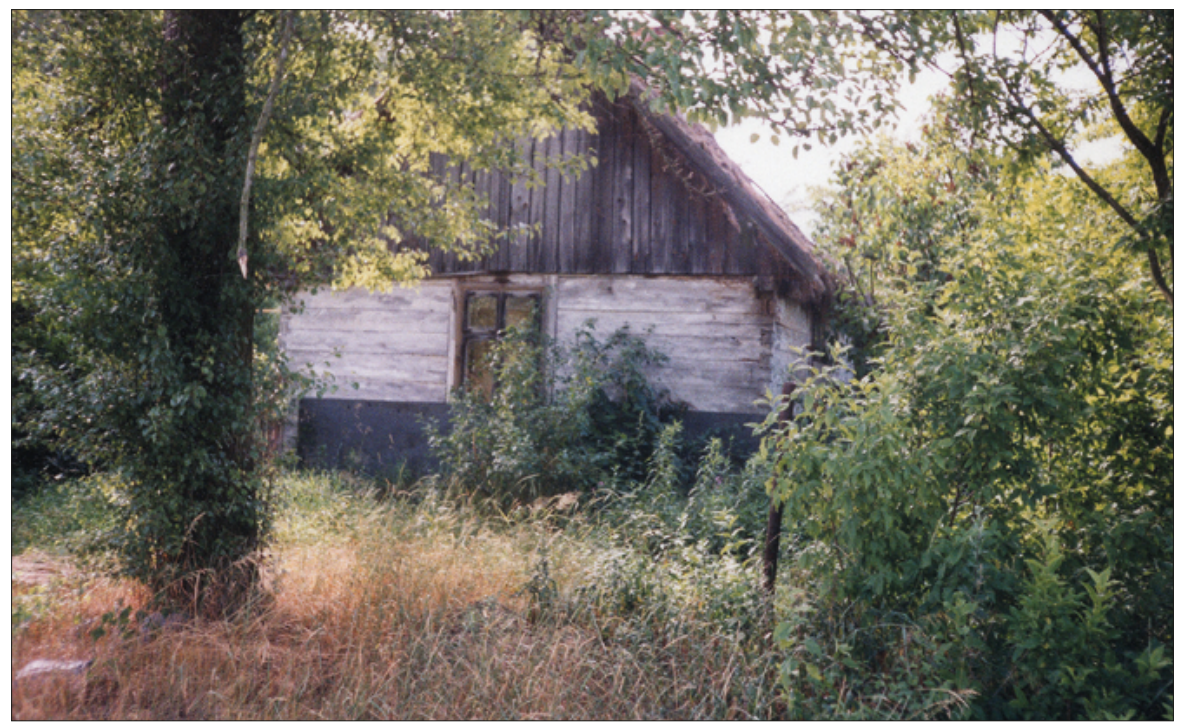

Fig. 1. A no longer existing German house in Kolonia Ujazd. Today, an entrance to a gravel pit is located there, 2004. Photograph by S. Latocha.

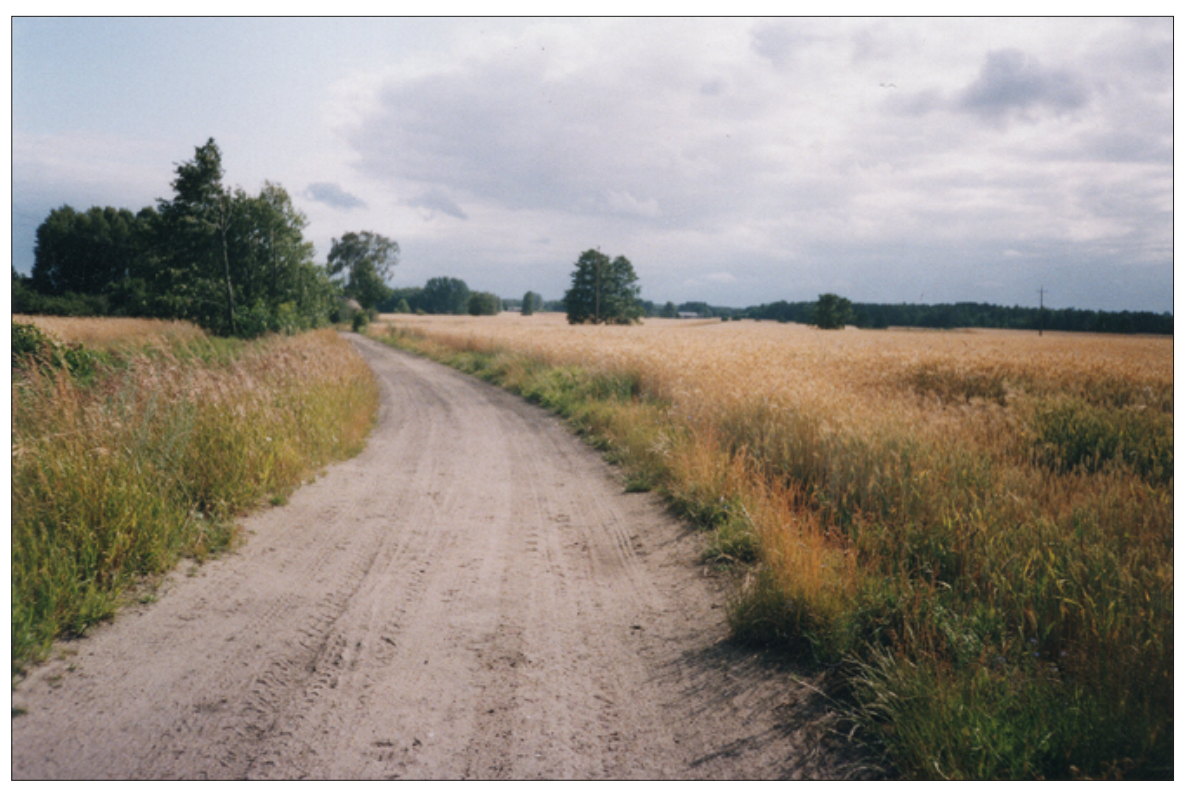

Fig. 2. The road leading to former German farmsteads in Kolonia Ujazd, 2004. Photograph by S. Latocha. 


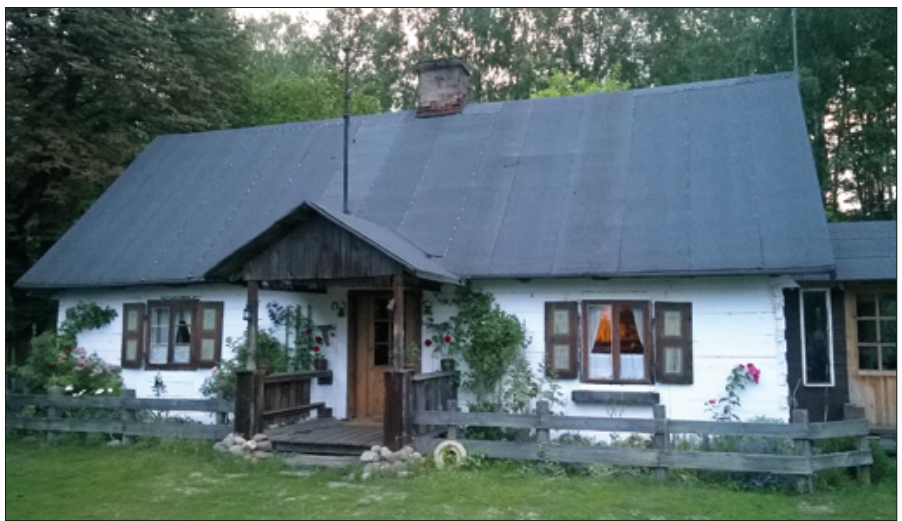

Fig. 3. A former

German house in Władysławów, today an agritourism farm Letnisko -Uroczysko owned by Mr. and Mrs. Zieliński, 2017. Photograph by S. Latocha.

$\mathrm{Uj} 2 \mathrm{zd}$, inia 11.11.1347 $\mathrm{x}$ :

1

$V_{1} / 27-1 / 9 / 47 \cdot-$

Do

Powl atowego Urze iो

Bezpleczés st tra Publi canego

w r z e zin 2 ch

iv ocponledzi na pismo z ania $8.10_{0} b_{0} r_{0}$ za Nr.RI/239/47,

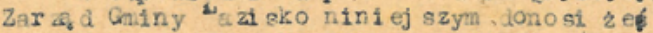

I. T czasie okupacj 1 na terenie tut. gminy zamleakivalo 355 volksdeut sohy.

2. obecnie zami eszije 181 Volksdeut achy nie liczoprzy dizi elon ych z O. o oza Fracy $\pi$ Si kawie.

3. Rei seut sche braz inne osoby nie posi acajqce obyitatel st wa pol siki ego narodowos di ni emi eckiej na terenie tut. Bminy nie zami eszkują.

4. zrehabilitowanych na tut, terenie ni ems.-
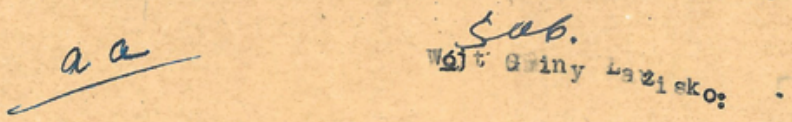

Fig. 4. A document of November 11, 1947, in which the Head of the Eazisko Commune with its seat in Ujazd states as follows: 1) During the war, there were 355 Volksdeutsche (ethnic Germans without German citizenship, living outside the Reich) in the commune; 2) There are 181 Volksdeutsche living in the commune now, except for those sent to the labour camp in Sikawa; 3) There are no Reichsdeutsche (ethnic Germans holding German citizenship, living in the country) in the commune now; 4 . There are no legally rehabilitated people. This document allows to estimate the scale of German settlement near Ujazd. APTM, 21, 320. 


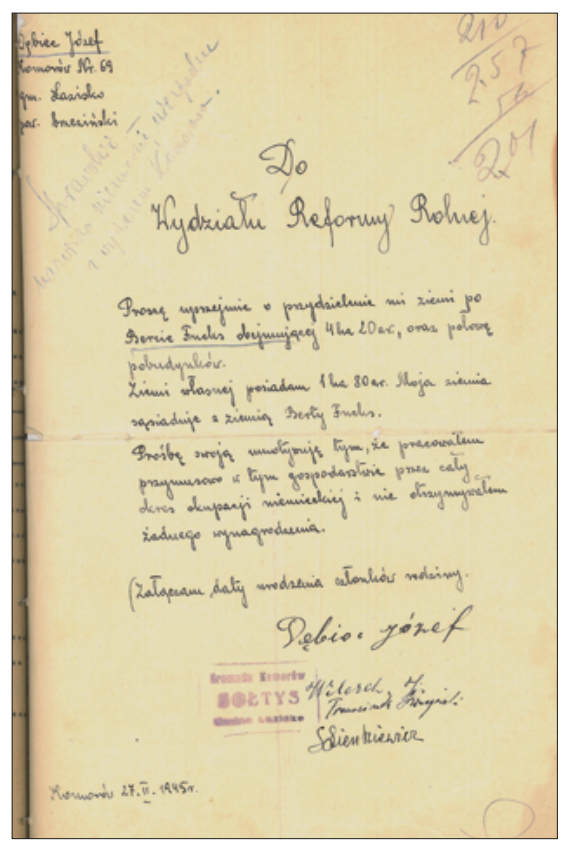

Fig. 5. A letter of application of February 27, 1945, in which Józef Dębiec asks for post-German land ( $4.2 \mathrm{ha}$ ) neighbouring his land (1.8 ha) in Komorowo.

The reason for the request is his forced labour without any pay for his German neighbours during the war.

APTM, 21, 288.

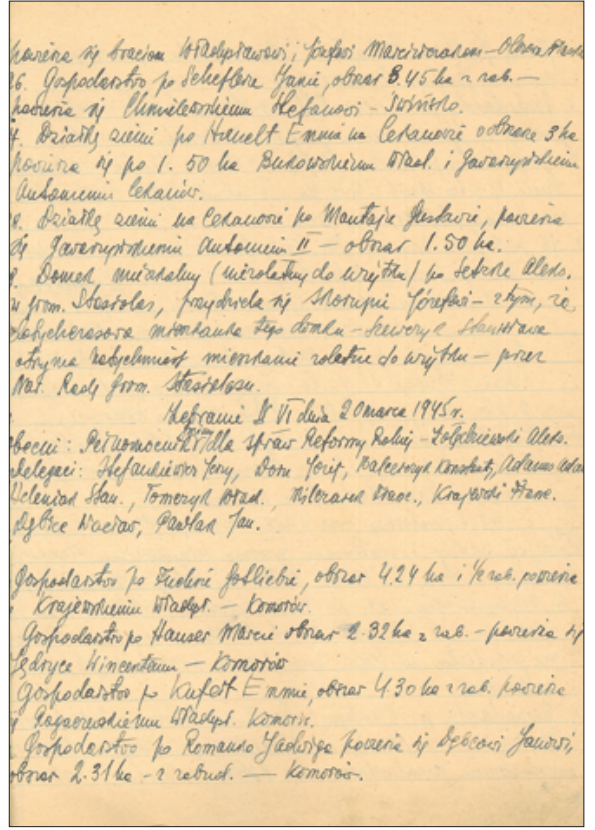

Fig. 6. A fragment of a protocol on division of the land formerly owned by Germans in the Łazisko Commune with its seat in Ujazd. Individual points provide the acreage, names of beneficiaries, and names of dispossessed Germans. Point 29 concerns my great-grandparents - Józef and Józefa Skorupa. APTM, 21, 287.

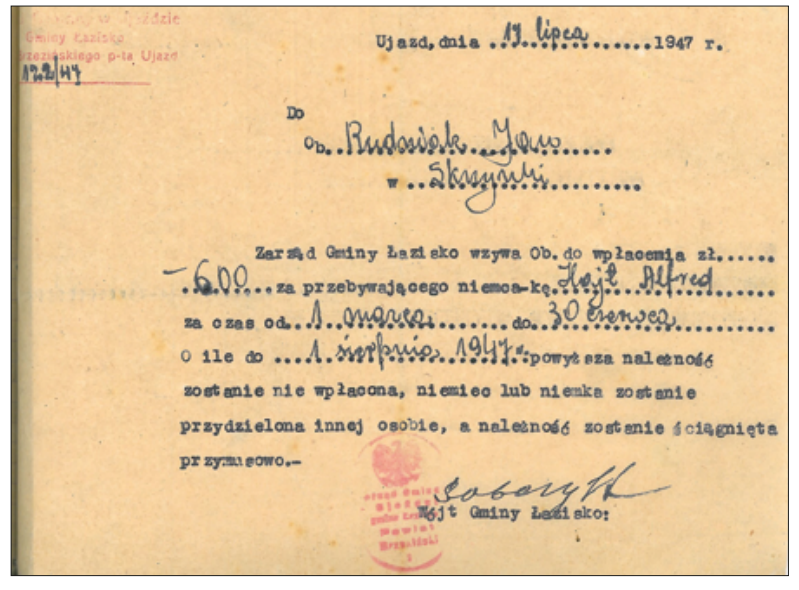

Fig. 7. A document of July 17, 1947, in which the head of the Łazisko Commune with its seat in Ujazd, call Jan Rudnik from Skrzynki to pay PLN 600 to the commune on pain of transferring the German serving him to a different farmstead. This document confirms that after the war and before their repatriation German inhabitants served on the farms of their Polish/Catholic neighbours. APTM, 21, 320. 